\title{
Arabization Planning: Algeria as an Instance
}

\author{
Dekhir Faiza \\ (Department of English, University of Saida, Saida, Algeria)
}

\begin{abstract}
Based on Al-Abed Al-Haq and Cooper's theoretical frameworks on language planning, this study is dedicated to describe Arabization from a language planning perspective. It also discusses how language planning can be used to provide a theoretical framework for Arabization planning. In order for these objectives to be achieved, the researcher goes through the following definitions: language planning definitions, Arabization definitions, presentation of an accounting scheme for the study of Arabization planning. This latter is said to increase our ability to describe and draw generalizations concerning Arabization planning.
\end{abstract}

Keywords: Arabization, Arabization planning, Language planning, Theoretical framework.

\section{INTRODUCTION}

According to Cooper [1] there is a general disagreement upon to what term should be utilized to refer to the policy of language planning, in the sense that some scholars have proposed the term language engineering (Miller, cited in Al-Abed Al-Haq [2]), others prefer to use language management to describe the activity (Jernudd and Neustupny [3]), language standardization, language elaboration and language reform.

In any given multilingual situation in the world, when one speaks of language planning, what immediately comes to mind is a set of strategies to solve various problems generated in such a multilingual context. Accordingly, language planning is said to focus on problem-solving or the planned pursuit of solutions to language problems, typically at the national level (Fishman, cited in Cooper [1]). As such language planning is characterized by the formulation and evaluations of alternatives for solving language problems to find the best, optimal, and most efficient decision (Rubin \& Jernudd [4]). A more pertinent definition might be that of (Jahr, cited in Eastman [5]) who claims that language planning includes an organized activity which attempts to solve language problems within a given context. Through language planning, efforts are made to direct, change, or keep the linguistic norm or the social status and communicative function of a given variety of language.

In this way, language planning has been referred to through different definitions by different scholars. However, all the definitions may fall under two rubrics:

- 1). A political and/ or administrative activity, also named status planning.

- 2). A linguistic activity, also labelled corpus planning.

Status planning involves the allocation of languages to different societal domains, such as the official status, education, business, and mass media (Kanta [6]). However, corpus planning refers to such activities as the production of grammars and dictionaries, the innovation of orthographies, spelling reforms...etc.

\section{ARABIZATION}

The term Arabization has been explained through many definitions based on varying views of authors. Even though the term refers to two broadly definable concepts, it is a ubiquitous term.

In one of its senses, Arabization is the extensive use of Arabic in all domains of life: political, social, and cultural i.e. it refers to the promotion of Arabic as a medium of interaction in public and private sectors (Grandguillaume [7] and others). In another sense, Sayadi [8] defines Arabization as lexical expansion which includes the coinage of new terms, either from existing words, or through translation of foreign terms.

According to Al-Abed Al-Haq [2], Arabicization is a more adequate term that has been coined to refer to the second sense, because it is morphologically derived from the language which is Arabic and therefore refers to the idea of Arabic language planning. However, Arabization refers more adequately to Arabs, i.e., the people and their behaviours.

Having defined Arabization in two spatially different concepts, it is worth noting that Arabicization planning refers to corpus planning; however, Arabization planning refers to status planning. Nonetheless, the terms are often used interchangeably.

Based on a number of careful investigations of Arabization in the Arab world, three important trends that Arabization has witnessed can be delineated: 1). pro-Arabization, 2). anti-Arabization, and 3). undecided Arabization (Al-Abed Al-Haq [2]). There are two groups within the first trend.

The first group is a fervent advocate to Arabization for religious matters. In this respect, Benrabah [9] mentions that this group is enthusiastic about the Arabic language for being the language of the Holy Qur'an. 
The second group is composed of protagonists to Arabization for nationalistic reasons. In this sense, (Suleiman, cited in Benrabah [9]) views that Arab nationalism is identical to the Arabic language.

Within the second trend, two attitudinal groups have emerged. The first holds instrumental orientations towards the use of a language. This group favors the target language (being English in the Middle East and French in North Africa) because of its stature as the 'language of bread' i.e., an international language affording practical benefits and advantages associated with using it (Vinod and Dipti [10]). Accordingly, learning French or English for these people is motivated by utilitarian motives (for example better job prospects).

According to Al-Abed Al-Haq [2] those people have good intentions and bear Arabization no ill-will. However, the second group displays integrative orientations towards the target language. More often than not, those people are called westernized people who wish to maintain the target language for social and interpersonal orientations. Lasagabaster [11] comments on these people's motives to establish closer bonds with the L2 community and language from a personal viewpoint.

Those people would claim: "Studying French can be important to us because it will enable us to better understand and appreciate French Canadian art and literature" or "Studying French can be important to us because it will allow to us to be more at ease with fellow Canadians who speak French" (Gardner cited in Lasagabaster [11]).

The third trend is not aware of the advantages either of Arabization or of the maintenance of target language (French or English).

\section{An Accounting Scheme for the Study of Arabization Planning}

Based on Cooper's definition of language planning, Arabization planning can be defined as a sum of deliberate efforts that influence the behaviour of Arabs with respect to the acquisition, structure, or functional allocation of the Arabic language, the ex-colonizer language and other regional dialects. Those efforts refer to corpus Arabization, status Arabization, and acquisition planning of Arabization. In this respect, Corpus Arabization refers to intervention in the forms of a language. It includes activities like: elaboration, cultivation, codification and standardization of Arabic (Robinson [12] and Gadelii [13]).

According to Quedraogo [14] status Arabization is mainly concerned with the allocation of languages or dialects to given status, for example: official, provincial, wider communication, international, capital, group, educational, literary, school subjects, and religious.

According to Al-Abed Al-Haq [2] acquisition planning of Arabization refers to the adoption of Arabization, Arabic language spread, and teaching-learning Arabic process.

In order to be able to understand, describe and analyze Arabization planning in a scrutinized way, it is a necessity to set some theoretical framework to develop Arabization planning. Cooper [1] suggests four crucial criteria to judge the success or un-success of language planning, which can be in turn useful criteria for the evaluation of Arabization planning: 1). Descriptive adequacy, 2) Predictive adequacy, 3) Explanatory adequacy, and 4) Theoretical adequacy:

- 1). Descriptive adequacy refers to one's success in expressing what happened in a given context. However, a scholar or investigator faces two broad questions: -What should be described? -On what basis should the description be evaluated?

- 2). Predictive adequacy refers to forecasting events. Arabization planning in Algeria is an illustrative example. The Algerian decision-makers suggested that after Arabization implementation there might be seen a gradual decrease in language diversity (pluralism) in Algeria, and hence a decrease in: bilingual education, bilingual government and public jobs, minority languages. This may make political monolingualism possible.

- 3). Explanatory adequacy refers to the ability to afford plausible explanations for the aforementioned predictions. According to Cooper [1] explanatory adequacy refers to the ability to account for particular outcome.

- 4). Theoretical adequacy deals primordially with the set of available variables that should be described, predicted, and explained in given situations. Accordingly, with no theory of language (Arabization) planning, no principled means are available to decide what factors should be included or excluded in descriptive, predictive, and explanatory studies.

As there is a no one agreed upon framework for Arabization planning, many disciplines and subdisciplines can be combined to better understand Arabization planning. Therefore, it is necessary to turn to frameworks proposed for marketing, for example.

\section{Arabization as an Instance of Marketing}

The analogy existing between Arabization planning and marketing may seem strange at first glance, for people are not used to view language use, structure, or acquisition as products that can be promoted. According to (Kotler, cited in Weinreich [15]) the concept of marketing holds that the organization's job is to control the 
desires and interests of target markets and to fetch the wanted satisfaction more effectively than competitors in a way that enhances the consumer's well-being.

Arabization is an instance of marketing in the sense that Arabic use, Arabic structure, proficiency and attitudes towards Arabic are products of Arabization whose acceptance can be marketed and promoted in the same way "the product managers of toothpaste, detergent, or automobile are marketed" Cooper [1]. Probably, one single nuance may exist between the two 'marketings' in that the primary aim of Arabization marketing is to encourage people to adopt behaviours that will enhance their own - and their citizens' lives. In other words, it looks for social good, while in commercial marketing the aim is merely 'financial'. However, this does not mean that commercial marketers cannot aid in the achievement of social good.

According to Kotler and Zaltman [16] the marketing problem is seen as "developing the right product backed by the right promotion and put in the right place at the right price"; these rubrics are referred to as "the four P's'.

\subsection{Product}

Unlike commercial marketing product, Arabization marketing product is not necessarily a tangible offering, it is a set of intangible ideas. A feasible product should be perceived by the language users as the best solution to the actual problem. Accordingly, products must be designed with specific features that appeal to target language user.

When the Algerian authorities, for instance, decide to assign Berber a national language position, they would find it useful to know which of the Berber dialects will be found most acceptable for nationhood standards.

\subsection{Promotion}

It consists of the integrated use of persuasion in order to induce language users to adopt communication innovation, whether acceptance is regarded as awareness, positive evaluation, or proficiency. The focus is on creating and supporting demand for the product. Advertisements, announcements, editorials, or media sponsorship are one way.

Language planners use a number of techniques of persuasion to promote their products, for instance, in the 1980's the Algerian High Council of the Arabic Language launched a set of decrees to adopt Standard Arabic in the sense that it invited the functionaries to attend the courses in the language that were daily presented in the administrations. Besides, the Council put signs and slogans like "Islam is my religion, Arabic is my language, and Algeria is my country", in public settings exhorting Algerians to use correct Arabic and be proud of their identity, ethnicity, and loyalty to the Arabic language. Language planners must be innovative and careful not to overwhelm their target adopters.

In this respect, Cooper [1] claims that in order for these techniques of persuasion to be viable, language planners sometimes award rewards or grants to motivate consciousness, interest, proficiency, or usage. In the first decades after Independence, the Algerian President Houari Boumedienne (1965-1978) employed means to promote the proficiency and use of Standard Arabic in different walks of life among which administration; for instance he made the knowledge of Standard Arabic an employment requirement for administrative jobs.

While language planners can use all of the persuasive devices available to any user, they may sometimes enjoy coercive power to compel and enforce language planning decisions; the Algerian authorities forbid any use of language other than Standard Arabic in public administrations. To fulfill their objective, they relied on punishing the functionaries by affording them very cheap salaries, imposing fees on them, or dismissing them from their job sectors.

\subsection{Price}

It refers to what the language user must do in order to obtain the social marketing product. It includes money costs, or it may instead require the language user "to give up intangibles", such as being fired from a company as a sign of embarrassment and disapproval. According to Moses [17] a language planner, like a marketer must balance costs with benefits.

In other words, if the product is priced too low, Kotler and Zaltman [16] say, the language user may perceive it as being not beneficial. On the other hand, if the price is too high, some will not be able to afford it. For instance, adults in Algeria, study English (as a foreign language) and/or French (as a second language) in private schools.

Neelam [18] implies that those people believe that knowledge of English (or French) will improve their earning capacities, so economic incentives are a good stimulus to this learning. Seemingly, they view that the projected financial benefits are higher than the present costs of schooling fees, efforts, or time while learning. 


\subsection{Place}

It describes the way that the product reaches the language user. It entails selection and development of appropriate means to decisions about the channels through which language users are reached with information or training (the product). This may include mass media channels. To take one example, language education system in Algeria very often functions as an instrument for the attainment of wider Arabization planning goals, particularly Arabization acquisition planning goals. However, this can be possible only if the language planners provided instruction materials, effective teachers in Arabic, and better teaching-learning locus to spread the use of Arabic.

\section{Conclusion}

A descriptively adequate account of Arabization planning can inform investigators, at least, of what actors attempted to influence what behaviours, of which people, for what ends, by what means, with what results, under what conditions. The marketing approach, for instance, seems to represent a bridging process that links scientists and economists' knowledge with that of language planners. In this way it offers a useful framework to improve capacities to describe, predict, explain, and draw generalizations about social matters that become more relevant and critical.

\section{REFERENCES}

[1] R. L. Cooper, Language Planning and Social Change (Cambridge University Press, 1989)

[2] F. Al-Abed Al-Haq, Toward a Theoretical Framework for the Study of Arabicization Planning, The first International conference on Literature, Linguistics, and Translation, Yarmouk University, Irbid, Jordan, 1994, 4-7.

[3] B. Jernudd and J. V. Neustupny, Language Planning: For Whom?, Comments presented at the International Colloquium on Language Planning in Ottawa, Canada, 1986.

[4] J. Rubin and B. Jernudd, Can Language Be Planned? Sociolinguistic Theory and Practice for Developping Nations. (East-West Center Press, Honolulu: The University of Hawaii Press, 1971).

[5] C. M. Eastman, Language Planning: An Introduction (San Francisco, Chandler and Sharp, 1983)

[6] D. C. Kanta, Parallel Education System: A Micro-Level Study of Murshidabad District, West Bengal, India, International Research Journal of Social Sciences, 2(1), 2013, 14-17

[7] G. Grandguillaume, La Francophonie en Algérie, Francophonie et mondialisation, no. 40, 2004, 75-97

[8] M. Sayadi, Arabization in the Arab World, in Arabization and its Role in Supporting the Arab Existence and Unity, (Beirut, Center of Arab Unity Studies, 1982)

[9] M. Benrabah, The Language Planning Situation in Algeria, Language Planning and Policy in Africa, vol. 2, Multilingual Matters LTD, 2007, 25-148

[10] B. Vinod and J. Dipti, Dominance of English in the Global market and the First Generation Learners (FGL), International Research Journal of Social Sciences, 1(1), 2012, 35-38.

[11] D. Lasagabaster, The Role of Instrumental and Integrative Attitudes in a Multilingual Context, Actas del II Simposio internacional sobre bilingüismo. Vigo: Universidad de Vigo, 2002, 1078-1085.

[12] D. Robinson, Language Policy and Planning: ERIC Digest, Clearinghouse on Languages and Linguistics (Washington DC, 1988)

[13] K. E. Gadelii, Language Planning: Theory and Practice: Evaluation of Language Planning Cases Worldwide, (Paris, UNESCO Language Division Education Sector, 1999)

[14] R. M. Quedraogo R.M., Language Planning and Language Policies in Some Selected West African Countries, (Burkina Faso, IICBA, 2000)

[15] N. K. Weinreich, What is Social Marketing?, Weinreich Communications, URL:www.social-marketing.com/Whatis.html,2006

[16] P. Kotler and G. Zaltman, Social Marketing: An Approach to Planned Social Change, Journal of Marketing, 35, 1971, 3-12

[17] I. Moses, Social Marketing, www.openarticle.com at URL: http://www.openarticle.com/article.cfm?id=CB198484-B178-484EB61FDC20F3B9E1F9, 2009

[18] M. Neelam, English Language is a link language in Social Strata: A Critical Review, International Research Journal of Social Sciences, 2(5), 2013, 30-38 